\title{
The Motion Decoupled Delivery System: A New Deployment System for Downhole Tools is Tested at the New Jersey Margin
}

\author{
by Peter B. Flemings, Peter J. Polito, Thomas L. Pettigrew, Gerardo J. Iturrino, Eric Meissner,
} Robert Aduddell, Donald L. Brooks, Chris Hetmaniak, David Huey, John T. Germaine, and

doi:10.2204/iodp.sd.15.07.2013

the IODP Expedition 342 Scientists

\section{Overview}

The Motion Decoupled Hydraulic Delivery System (MDHDS) is a new downhole tool delivery system that is deployed by wireline and uses drillstring pressure to advance a penetrometer (or other downhole tool) into the formation at the bottom of offshore boreholes. After hydraulic deployment of the penetrometer, it is completely decoupled from the BHA; this eliminates the adverse effects of ship heave. We tested the MDHDS at Site U1402 (the location of Site 1073, ODP Leg 174A), offshore New Jersey, during two days of ship time during Integrated Ocean Drilling Program (IODP) Expedition 342. In one deployment we emplaced a penetrometer successfully and documented that it was decoupled from drillstring movement. Based on this successful field test, the MDHDS has been certified by the U.S. Implementing Organization (USIO) for shipboard use. The MDHDS will replace the previous deployment system, the Colletted Delivery System. The MDHDS is an IODP-funded engineering development led by The University of Texas at Austin, in conjunction with the USIO and Stress Engineering Services. This sea trial was the culmination of a seven-year development effort that included extensive engineering design and fabrication.

\section{Introduction}

We make downhole measurements in the IODP with 1) wireline logging or logging-while-drilling (LWD) tools that profile the borehole, 2) permanent observatories at the seafloor, and 3) downhole tools that interact with the formation at specific depths. Wireline logging or LWD is used throughout the drilling program to measure physical properties and for interpreting everything from formation pressure (Moore et al., 1995) to sedimentology and climate change (Hesselbo, 1996). We generally rely on oil field service company products for logging. However, tools also have been developed specifically for deployment within the IODP (Goldberg et al., 2004). Over the last two decades, we have made extraordinary investments in borehole observatories to measure geochemical and hydrological properties (Becker and Davis, 2005). Finally, we have a limited number of downhole tools that make measurements at specific depths when a borehole is drilled. The Advanced Piston Corer Temperature tool (APCT) and the Sediment Temperature tool (SET), previously known as the Davis-Villinger Temperature Probe
(DVTP), are used to take temperature measurements. The Sediment Temperature Pressure tool (SET-P), previously known as the Davis-Villinger Temperature Pressure Probe (DVTP-P), the Temperature Two Pressure probe (T2P), and the Piezoprobe are used to take pressure measurements in semi-consolidated rocks. More recently, with the use of wide diameter drillpipe or riser drilling system, we have also begun to make direct pressure and stress measurements with the Modular Formation Dynamics Tester (MDT) of Schlumberger (Boutt et al., 2012; Lin et al., 2010).

The SET, SET-P, Piezoprobe, and T2P are borehole penetrometers. They are lowered down the borehole inside the drill pipe to the bottom of the borehole and driven vertically downwards by the weight of the drillstring into the formation. The SET records the frictional heating that results when the tool is driven in and the subsequent temperature dissipation; in situ temperature and the thermal diffusivity can be derived from these data. The SET-P, Piezoprobe, and T2P record pore pressure during insertion and during subsequent dissipation from which the in situ pressure and the coefficient of consolidation can be derived. The SET-P and T2P also record temperature. The SET-P was deployed during ODP Legs 190, 201, and 204 (D'Hondt et al., 2003; Moore et al., 2001;

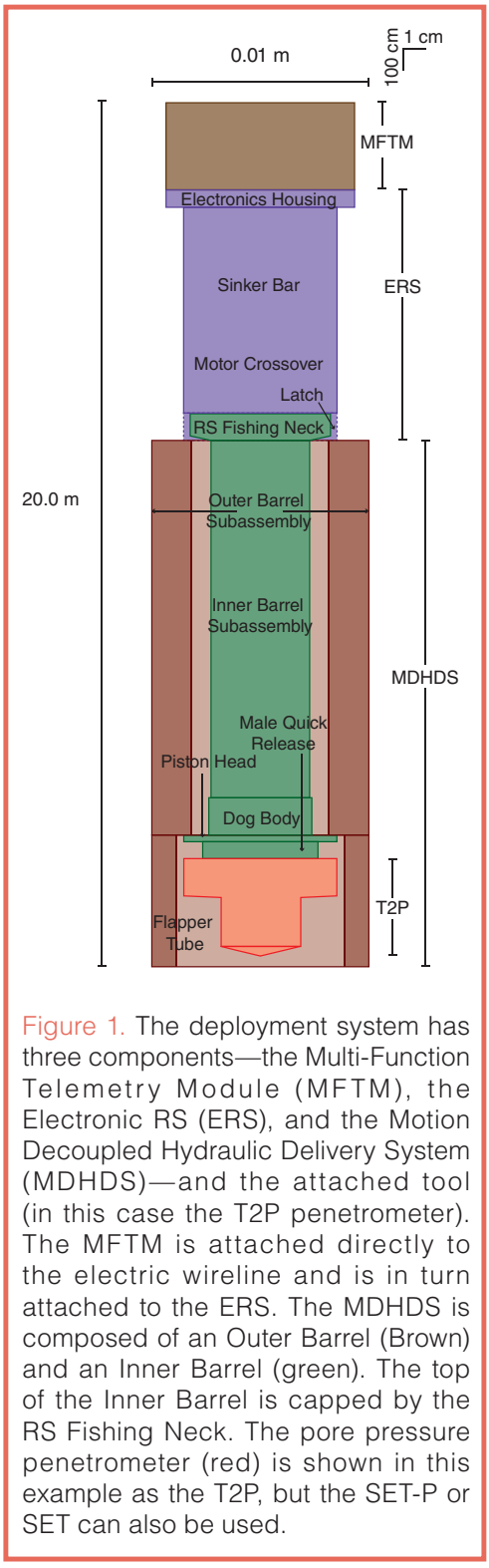


Tréhu et al., 2003). The Piezoprobe was deployed during ODP Leg 204 (Long et al., 2007), whereas the DVTP-P and T2P were deployed during IODP Expedition 308 (Flemings et al., 2005, 2008; Long et al., 2008).

The ability to measure in situ pressure and temperature rapidly and at multiple depths during an expedition provides an important capability to address problems described in the new IODP Science Plan. These measurements allow us to map heat and fluid flow, provide valuable constraints for analyzing climate change, and help in our understanding of the Earth's dynamic systems, which are themes within the 2013-2023 IODP Science Plan. For example, we can determine slope stability (when and how submarine landslides form), interpret whether recent warming has occurred from the temperature profile, and illuminate how pore pressure impacts deformation in convergent margins.

Although penetrometer deployments in the IODP have yielded exciting results, they have also been challenging because the penetrometer is often dislodged from the formation. During IODP Exp. 308, in more than half of all deployments-and in all deployments at less than $100 \mathrm{mbsf}$ - the penetrometer was dislodged (Flemings et al., 2008). Uncoupling is recorded by a rapid drop in the
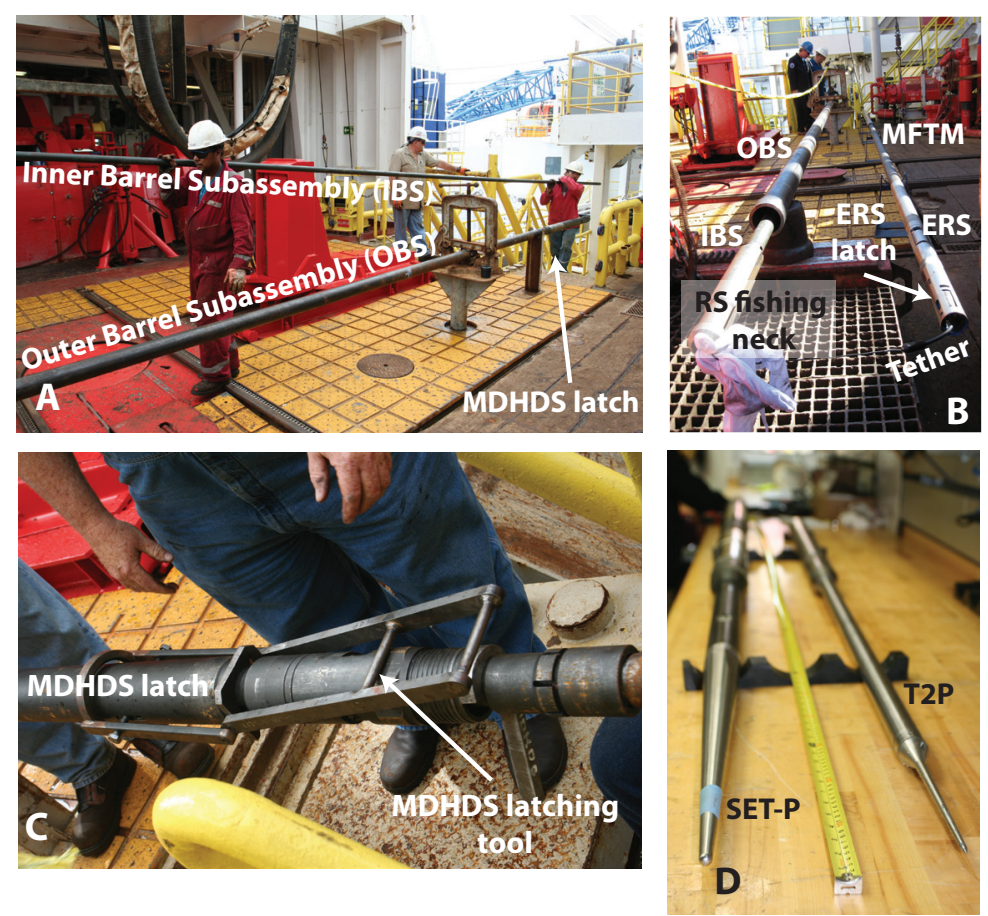

Figure 2. [A] The Inner Barrel Subassembly (IBS) and the Outer Barrel Subassembly (OBS). [B] Left: the IBS lies inside the OBS. The fishing neck of the IBS is shown on the lower left. Right: the ERS is connected to the MFTM, which is connected to the logging line. The ERS Latch is at the bottom of the ERS assembly. [C] The MDHDS Latch and latching tool. The latch is set on the rig floor, and this fixes the IBS to the OBS. When the drillstring is pressurized, this latch is released, and the IBS slides freely from the OBS. [D] The SET-P and the T2P are two pore pressure penetrometers available for use in the drilling program.

measured pressure and by tool movement (recorded by the accelerometer) when the BHA is raised after the penetrometer is inserted. This compromises the measurement of in situ pressure. The DVTP-P pressure records from Legs 201 and 204 also show that tool dislodgement has been a persistent problem (D’Hondt et al., 2003; Tréhu et al., 2003). In addition, when a narrow diameter penetrometer such as the $\mathrm{T} 2 \mathrm{P}$ is used, the tip is often bent or destroyed, either because the tool is poorly aligned when it is pushed into the formation or because it is bent when it passes through the flapper valve at the drill bit (Flemings et al., 2006).

The T2P and SET-P penetrometers have been deployed by wireline on the Colleted Delivery System (CDS). The CDS is analogous to an old-style pointer, in which a series of cylinders slide past each other to increase or decrease the system's length. In this configuration, the penetrometer is pushed into the formation by the drillstring, and then the drillstring is raised several meters. Decoupling of the drillstring from the penetrometer is achieved by the expansion and contraction of the CDS. We attribute the dislodgement of the penetrometer to be due to friction within the CDS that pulls the penetrometer out when the drillstring is raised, or to "swabbing" (the suction induced by raising the drillstring).

In 2005 we began a seven-year project to design, build, and test a new deployment system called the Motion
Decoupled Hydraulic Delivery System (MDHDS). This wireline-deployed system uses drillstring pressure to advance a penetrometer into the formation. After hydraulic deployment of the penetrometer, it is completely decoupled from the BHA to eliminate the adverse effects of ship heave. We completed three separate land tests at Schlumberger's Sugarland Test Facility and numerous other bench-top tests at Stress Engineering Services, LDEO, and The University of Texas at Austin. In June 2012, we held a final field test on the JOIDES Resolution during IODP Expedition 342. A full description of this engineering development is available (Shipboard Scientific Party, 2013). We summarize the MDHDS development and the final field test at Site U1302 below.

\section{The New Deployment System}

The MDHDS is part of a three-component system (Fig. 1). The Multi-Function Telemetry Module (MFTM) allows real-time communication with the ERS and other tools. The Electronic "RS" (the ERS; "RS" is an oil field designation for a particular geometry of fishing tool) delivers and retrieves the MDHDS and the attached downhole tool to the Bottom Hole Assembly (BHA). The MDHDS, once seated in the $\mathrm{BHA}$, is the platform from which the penetrometer (or some tool to be designed in the future) is deployed. 


\section{Multi-Function Telemetry Module (MFTM)}

The MFTM (Fig. 1) is a downhole sonde that allows real-time communication with downhole tools through the Schlumberger armored 7-conductor cable. The MFTM was developed by the Lamont-Doherty Earth Observatory (LDEO) Borehole Research Group, and it is used to activate the latching of the ERS and to capture data streams from probes attached to the inner core barrel of the MDHDS assembly.

\section{Electronic RS (ERS) System}

The ERS tool (Figs. 1, 2) was developed for use with the Simple Cabled Instrument for Measuring Parameter In-situ (SCIMPI) system, and the MDHDS. The ERS deploys and retrieves the MDHDS (or any downhole tool) within the drillpipe on the electric wireline. The ERS has a snaplock and is latched at the surface; the tool is lowered into the borehole, where an electric motor within the ERS is commanded from the surface to rotate until the RS pulling neck on the downhole instrument is released. This motor can unlock the ERS from the downhole tool and return the ERS to a locked position so that it can be used to retrieve the downhole tool. The ERS consists of an electronics section, wired through sinker bars, and a motor section that contains the latching mechanism at the bottom of the tool. A prototype of the ERS was used on IODP Expedition 327 to successfully deploy the Hole U1301B CORK system (Expedition 327 Scientists, 2011).

\section{The Motion Decoupled Hydraulic Delivery System}

The MDHDS is composed of an Inner Barrel Subassembly (IBS, Figs. 1, 2a), an Outer Barrel Subassembly (OBS, Fig. 1), and the MDHDS Latch. The penetrometer is attached to the IBS. On the rig floor, before the MDHDS is deployed, the IBS is latched to the OBS. The latching system (MDHDS Latch), near the bottom of the MDHDS (Fig. 1), is cocked by shifting a latch piston, compressing a spring within the MDHDS Latch, and then shifting an internal sleeve to lock the latch piston in place (Fig. 2c). The internal sleeve is then held in place by shear pins. The latched MDHDS is conveyed by wireline by the ERS to sit on the landing shoulder of the standard BHA. The MDHDS Latch is activated by raising the drillstring pressure. This severs the two shear pins, which allow the internal sleeve to move, unlocking the latch piston, which remains held in place by the drillstring pressure. Relieving the drillstring pressure allows the spring to expand, moving the latch piston, and opening the latch. The IBS is then freed from the OBS.

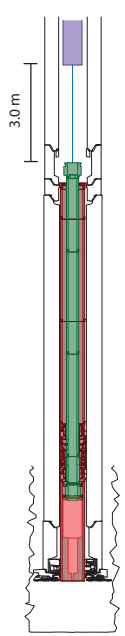

B

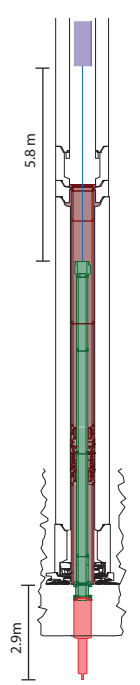

C

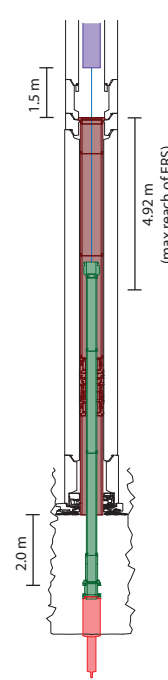

$\mathrm{D}$
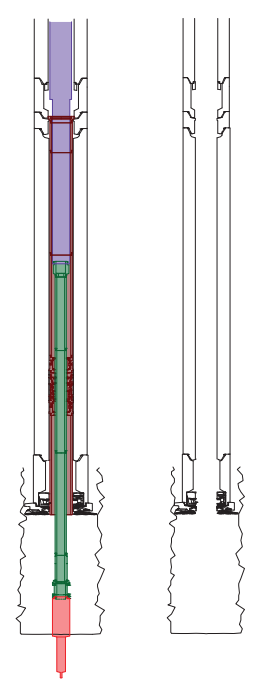

E gure 3. MDHDS deployment diagram. The MFTM and the ERS are purple, the inner Barrel (IBS) is green, the OBS is brown, and the penetrometer is pink (See . RS releases the MDHDS and is raised $3 \mathrm{~m}$. [C] After drillstring pressurization, 列 commodation. [E] Once the test is complete, the ERS is lowered and latched the RS fishing neck. [F] The entire unit is brought to the surface.

The IBS and penetrometer is then pumped into the formation by raising the drillstring pressure. When using a narrow diam-eter penetrometer like the T2P, the bottom of the MDHDS can be outfitted with a flapper guide tube. This tube protects the penetrometer as it passes through the flapper at the drill bit and acts as a guide to ensure vertical deployment. For larger diameter penetrometers like the SET-P, the flapper guide tube is not used.

During this test, we installed a tension device inside the IBS to house a communications tether. The tether allowed real-time communication from the penetrometer to the rig floor. This tension device-consisting of a rigid and elastic cable and a series of pulleys-held the communications tether in tension at all times, taking up slack as the drillstring heaved downward and letting it out as it heaved upward. The tether connected to the top of the T2P and the bottom of the ERS.

\section{Deployment Procedure}

The MDHDS is first latched at the rig floor (Fig. 2c). The penetrometer is then attached to the bottom of the IBS. The MDHDS and the penetrometer are then hung vertically on the rig floor in the drillpipe. The cable head, MFTM, and ERS assembly are then snap-locked to the IBS, and the MDHDS is lowered on the electric wireline. The MDHDS is landed in the BHA with the BHA positioned $1.5 \mathrm{~m}$ above the bottom of the hole (Fig. 3a).

The MFTM actuates the ERS to unlatch the MDHDS, and the ERS is raised $3 \mathrm{~m}$ (Fig. $3 \mathrm{~b}$ ). With the MDHDS 
latched and landed in the BHA, all the drillstring fluid is forced through the center of the OBS through a contact seal between the MDHDS landing shoulder and the wall of the BHA. Next, the drillstring is slowly pressurized to approximately $8 \mathrm{MPa}$ (1160 psi) and held for several minutes to actuate the latch mechanism. Pressure is then released and, upon pressure reduction, the latch is opened. Next, the drillstring is re-pressurized, and the probe is pumped into the formation (Fig. 3c). The probe can be driven a maximum of $2.9 \mathrm{~m}$ because after that a circulation path is established and there is no longer any driving pressure. The BHA is then raised $2 \mathrm{~m}$ (Fig. 3d), allowing for $+/-2.5 \mathrm{~m}$ of vertical motion. At this point in the deployment, the OBS is fixed relative to the BHA, and the IBS is fixed relative to the bottom of the hole. There are no seals in contact between the IBS and OBS; thus, no seal friction exists that could induce heave motion into the probe.

The probe is extracted by using the MFTM for actuating the ERS into a closed position, lowering the MFTM-ERS assembly until latching with the RS fishing neck that is attached to the IBS (Fig. 3e). The probe is then pulled from the formation into the OBS (Fig. 3f), where it is well protected during the trip out of the hole. If the probe is embedded so firmly into the formation that the wireline cannot lift, then the BHA can be raised to dislodge the probe from the bottom.

The MDHDS is retrieved by wireline. On deck, it is laid out as a normal core barrel would be. The flapper tube is removed to allow access to the T2P, which is then detached from the IBS by disconnecting a quick-release connection.

The MDHDS latch is then reset in preparation for the next deployment.

\section{Site U1402 Deployment}

At Site U1402, the continental slope is smooth, draped by sediments from the Hudson River apron, and the water depth is 639 m. During ODP Leg 174A, Advanced Piston Cores (APC) were taken to 215 mbsf (meters below sea floor). Sediments within the first $200 \mathrm{mbsf}$ were dominated by silty clay (Shipboard Scientific Party, 1998).

The new hole at the previous Site 1073 was named Site U1402 and was spudded on 7 June 2012. The seafloor was recorded at 650 meters below rig floor (mbrf). The hole was washed down to $96.4 \mathrm{mbsf}$ (746.4 mbrf), and the MDHDS, T2P, and the ERS were assembled and deployed. The MDHDS was lowered by the ERS to the BHA. The ERS was unlatched with the tether system in place and raised two meters above the BHA. The drillstring pressure was raised, and the T2P penetrometer was deployed (Fig. 4).

After the MDHDS Latch was released, the T2P and IRS passed through the BHA and into the formation under their own weight, driving the tip of the T2P into the formation, but not far enough to drive the shaft pressure port into the formation (Fig. 4, Pt. A). After we increased the drillstring pressure a second time, the entire tool was driven approximately $2.9 \mathrm{~m}$ farther into the formation until circulation was established (Fig. 4, Pt. B). Between Points C and D (Fig. 4), circulation was maintained, and pore pressure varied but declined slightly. At Pt. D, the pumps were shut off, and the pressure data recorded a dissipation characteristic of a penetrometer deployment.

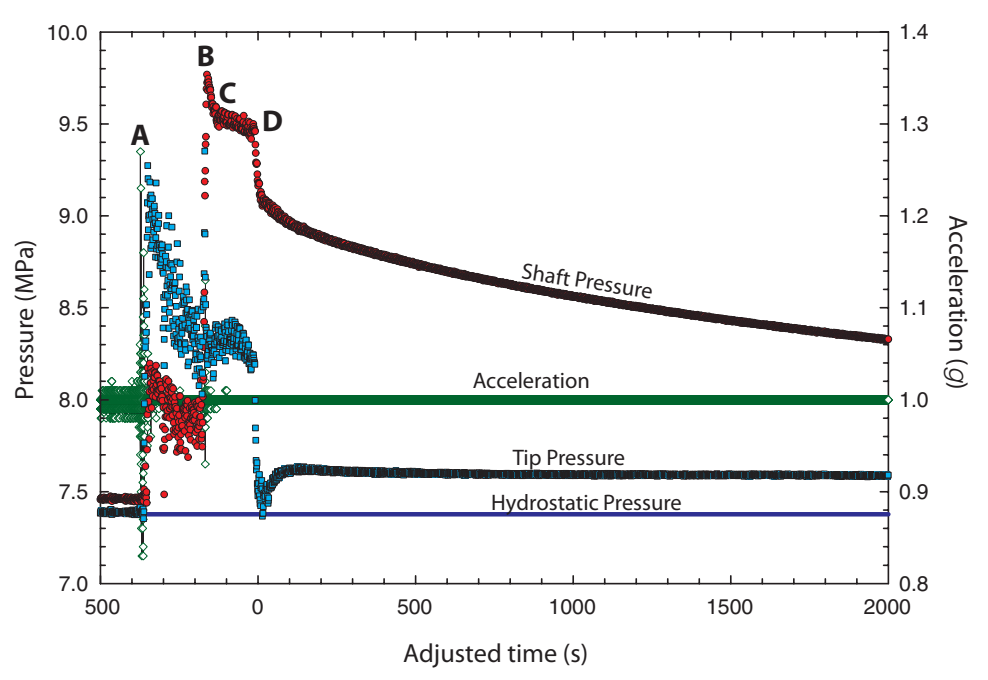

Figure 4. MDHDS deployment record. Zero time is set to the onset of pressure dissipation. At Pt. A (-400 s), the MDHDS latch is released, and the IBS and the attached T2P descend by gravity driving the tip a small distance into the formation. As a result, the tip pressure (blue) and the shaft pressure (red) rise abruptly. The accelerometer (green) records rapid changes in acceleration. At Pt. B, the drillstring is re-pressurized, and the penetrometer is driven into the formation (e.g., Fig. 3c). At Pt. C, we interpret that the penetrometer has been driven the maximum $2.9 \mathrm{~m}$ of stroke that is possible (Fig. 3c). Between Pt. C and Pt. D, there is ongoing circulation but no longer any significant driving force. At Pt. D, the circulation pumps are turned off, and pressure dissipation begins.
When circulation was re-established to clear the BHA of settled sediment, the tool jammed. The ERS was released and the wireline was pulled from the hole; the top drive was then set back, and the drillstring was tripped from the hole. After drillpipe retrieval, we found that the tether within the IBS had snapped and worked between the tool and the inside of the BHA aperture, jamming the tool in place and preventing recovery.

\section{Interpretation of Results}

The MFTM, ERS, and MDHDS worked well in this deployment. The IBS and T2P successfully unlatched and were deployed after drillstring pressurization (Fig. 4, Pt. A). When the drill string was re-pressurized, the penetrometer was successfully driven into the formation (Fig. 4, Pt. B). After penetration, both the tip and shaft pressure sensors recorded smooth pressure dissipation profiles. The lack of any motion in the accelerometer (green triangles, Fig. 4) during the dissipa- 


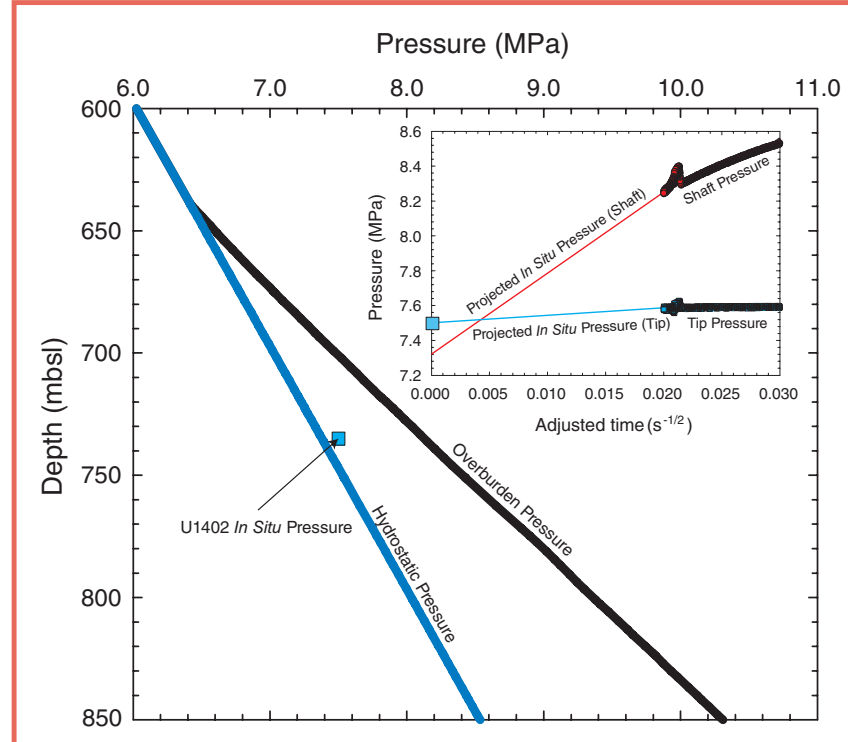

Figure 5. Pressure/stress vs. depth plot at Site U1302. The overburden stress is interpreted from Site 1073 density data (Shipboard Scientific Party, 1998). The in situ pore pressure, as extrapolated from the tip pressure (inset) is interpreted to be $7.54 \mathrm{MPa}$. Inset: a plot of tip and shaft pressure vs. the inverse square root of time. For both the tip and the shaft pressure, the pressure is extrapolated linearly to zero-time to estimate the in-situ pressure (e.g. Flemings et al., 2008).

tion interval is evidence that the drillstring completely decoupled from the penetrometer. Finally, the penetrometer was undamaged when it was recovered, which indicates that it was driven straight downward and that there were no problems with the flapper valve at the bottom of the BHA.

The pressure records are characteristic of those recorded by successful T2P deployments (Flemings et al., 2008). The shaft pressure (Fig. 4) is higher than the tip pressure because the larger diameter shaft induced a larger pore pressure during penetration. The pressure rebound recorded at the tip (0-50 seconds, Fig. 4) is due to the unloading that resulted when circulation stopped. Extrapolation of the tip pore pressure record (Fig. 5, inset) results in a predicted in situ pressure of $7.54 \mathrm{MPa}$ (blue square, Fig. 5), which is slightly above hydrostatic pressure. Similar results were predicted by Dugan and Flemings (2000) based on an indirect measurement with respect to bulk density.

\section{Long-Term Application}

Based on the outcome of this engineering test, the MDHDS, the T2P, and MFTM have been certified for deployment on board the JOIDES Resolution. Although real-time data were acquired through the tethered system, failure of the tether during drillstring pressurization shows that a tethered real-time telemetry configuration is not ready for regular shipboard use. Stress Engineering Services is completing final modifications to the ERS to improve its latching operation. Once the modifications are complete, this tool will also be certified for onboard deployment by USIO. The ERS will be used to deploy the SCIMPI during
IODP Expedition 331S in May of 2013. We hope that the advances in tool delivery allowed by the MDHDS will result in rich pore pressure and temperature data sets in future expeditions and will engender the development of new downhole tools that can be deployed by the MDHDS.

\section{Acknowledgements}

We thank the entire crew of Expedition 342, especially the electronics technician, machinists, engineers, and the drilling crew. We express our gratitude to the crew on the Schlumberger Genesis Rig where much of the land-based testing took place. Additionally, we are indebted to Michael Meiring, Yoshi Kawamura, Eddie Wheeler, Dean Ferrell, Tessa Green, David Braley, and James Piper. Support for this work came from an IODP Engineering Development Grant, the Jackson School of Geosciences, the U.S. Science Support Program, and the UT GeoFluids Consortium. This project was managed by the University of Texas at Austin with participation from Stress Engineering Services, Pettigrew Engineering, the Borehole Research Group at LamontDoherty Earth Observatory (LDEO), and the Engineering Services Group at Texas A\&M.

\section{The IODP Expedition 342 Scientists}

R.D. Norris (Co-chief Scientist), P.A. Wilson (Co-chief Scientist), P. Blum (Expedition Project Manager/Staff Scientist), A. Fehr, C. Agnini, A. Bornemann, S. Boulila, P.R. Bown, C. Cournede, O. Friedrich, A.K. Ghosh, C.J. Hollis, P.M. Hull, K. Jo, C.K. Junium, M. Kaneko, D. Liebrand, P.C. Lippert, Z. Liu, H. Matsui, K. Moriya, H. Nishi, B.N. Opdyke, D. Penman, B. Romans, H.D. Scher, P. Sexton, H. Takagi, S.K. Turner, J.H. Whiteside, T. Yamaguchi, Y. Yamamoto

\section{References}

Becker, K., and Davis, E. E., 2005. A review of CORK designs and operations during the Ocean Drilling Program. In Fisher, A. T., Urabe, T., Klaus, A., and the Expedition 301 Scientists, Proc. IODP, 301: Washington, DC (Integrated Ocean Drilling Program Management International, Inc.). doi:10.2204/iodp.proc.301.104.2005

Boutt, D. F., Saffer, D., Doan, M.- L., Lin, W., Ito, T., Kano, Y., Flemings, P. B., et al., 2012. Scale dependence of in situ permeability measurements in the Nankai accretionary prism: The role of fractures. Geophys. Res. Lett., 39:L07302. doi:10.1029/2012GL051216

D’Hondt, S. L., Jørgensen, B. B., Miller, D. J., et al., 2003. Proc. ODP, Init. Repts., 201: College Station, TX (Ocean Drilling Program), [CD-ROM].

Dugan, B., and Flemings, P. B., 2000. Overpressure and fluid flow in the New Jersey continental slope: Implications for slope failure and cold seeps. Science, 289(5477):288-291. doi:10.1126/ science.289.5477.288

Expedition 327 Scientists, 2011. Expedition 327 summary, In Fisher, A. T., Tsuji, T., Petronotis, K., and the Expedition 327 
Scientists, Proc. IODP, 327: Washington, DC (Integrated Ocean Drilling Program Management International, Inc.). doi:10.2204/iodp.proc.327.101.2011

Flemings, P. B., Behrmann, J., Davies, T., John, C., and the Expedition 308 Project Team, 2005. Gulf of Mexico hydrogeologyoverpressure and fluid flow processes in the deepwater Gulf of Mexico: Slope stability, seeps, and shallow-water flow. IODP Sci. Prosp., 308. doi:10.2204/iodp.sp.308.2005

Flemings, P. B., Behrmann, J., John, C. M., and the Expedition 308 Scientists, 2006. Proc. IODP, 308: Washington, DC (Integrated Ocean Drilling Program Management International, Inc.). doi:10.2204/iodp.proc.308.2006

Flemings, P. B., Long, H., Dugan, B., Germaine, J., John, C. M., Behrmann, J. H., and Sawyer, D., 2008. Erratum to "Pore pressure penetrometers document high overpressure near the seafloor where multiple submarine landslides have occurred on the continental slope, offshore Louisiana, Gulf of Mexico" [Earth and Planetary Science Letters 269/3-4 (2008) 309-32]. Earth Planet. Sci. Lett., 274(1-2):269-283. doi:10.1016/j.epsl.2008.06.027

Goldberg, D., Meltser, A., Myers, G., and Masterson, W., 2004. Comparison of Multi-Sensor Spectral Gamma Ray Tool (MGT) and conventional spectral gamma ray logs, ODP Site 1179. Proc. ODP, Sci. Results, 191: College Station, TX (Ocean Drilling Program).

Hesselbo, S. P., 1996. Proc. ODP, Sci. Results, 150: College Station, TX (Ocean Drilling Program).

Lin, W., Doan, M.- L., Moore, J. C., McNeill, L., Byrne, T. B., Ito, T., Saffer, D., et al., 2010. Present-day principal horizontal stress orientations in the Kumano forearc basin of the southwest Japan subduction zone determined from IODP NanTroSEIZE drilling Site C0009. Geophys. Res. Lett., 37:L13303. doi:10.1029/2010GL043158

Long, H., Flemings, P. B., and Germaine, J. T., 2007. Interpreting in situ pressure and hydraulic properties with borehole penetrometers in ocean drilling: DVTPP and Piezoprobe deployments at southern Hydrate Ridge, offshore Oregon. J. Geophys. Res., 112:B04101. doi:10.1029/2005JB004165

Long, H., Flemings, P. B., Dugan, B., Germaine, J. T., and Ferrell, D., 2008. Data report: Penetrometer measurements of in situ temperature and pressure, IODP Expedition 308. In Flemings, P. B., Behrmann, J. H., John, C. M., and the Expedition 308 Scientists, Proc. IODP, 308: Washington, DC (Integrated Ocean Drilling Program Management International, Inc.). doi:10.2204/iodp.proc.308.203.2008

Moore, G. F., Taira, A., Bangs, N. L., Kuramoto, S., Shipley, T. H., Alex, C. M., Gulick, S. S., et al., 2001. Structural setting of the Leg 190 Muroto Transect. In Moore, G.F., Taira, A., Klaus, A., et al., Proc. ODP, Init. Repts., 190:College Station, TX (Ocean Drilling Program), [CD-ROM].

Moore, J. C., Shipley, T. H., Goldberg, D., Ogawa, Y., Filice, F., Fisher, A., Jurado, M. J., et al., 1995. Abnormal fluid pressures and fault-zone dilation in the Barbados accretionary prism: Evidence from logging while drilling. Geology, 23(7):605-608. doi:10.1130/0091-7613(1995)023<0605:AFP $\mathrm{AFZ}>2.3 . \mathrm{CO} ; 2$
Shipboard Scientific Party, 1998. Site 1073. In Austin, Jr., J. A., Christie-Blick, N., Malone, M. J., et al., Proc. ODP, Init. Repts., 174A: College Station, TX (Ocean Drilling Program), 153-191. doi:10.2973/odp.proc.ir.174a.105.1998

Shipboard Scientific Party, in press. Site 342. In Norris, R., Wilson, P., and Blum, P., Proc. ODP, Init. Repts., 211: College Station, TX (Ocean Drilling Program).

Tréhu, A. M., Bohrmann, G., Rack, F. R., and Torres, M. E., 2003. Proc. ODP, Init. Repts., 204: College Station, TX (Ocean Drilling Program). doi:10.2973/odp.proc.ir.204.102.2003

\section{Authors}

Peter B. Flemings, Peter J. Polito, and Donald L. Brooks, Jackson School of Geosciences, The University of Texas at Austin, 1 University Station C1100, Austin, TX 78712-0254, U.S.A., e-mail: pflemings@jsg.utexas.edu, peter.polito@jsg.utexas.edu, brodon@ig.utexas.edu

Thomas L. Pettigrew, Pettigrew Engineering, 479 Nine Mile Road, Milam TX 75959, U.S.A., e-mail:tom.pettigrew@ windstream.net

Gerardo J. Iturrino, and Eric Meissner, Borehole Research Group, Lamont-Doherty Earth Observatory of Columbia University, P.O. Box 1000, 61 Route 9W, Palisades, NY 10964, U.S.A., e-mail:iturrino@ldeo.columbia.edu, meissner@1deo.columbia.edu

Robert Aduddell, Integrated Ocean Drilling Program, Texas A\&M University, 1000 Discovery Drive, College Station, TX 77845-9547, U.S.A., e-mail:aduddell@iodp.tamu. edu

Chris Hetmaniak, and David Huey, Stress Engineering Services, 13800 Westfair East Drive Houston, TX 77041, U.S.A., e-mail:chris.hetmaniak@stress.com, dave.huey@ stress.com

John T. Germaine, Department of Civil and Environmental Engineering, Massachusetts Institute of Technology, Cambridge, MA 02139, U.S.A., e-mail:jgermain@mit.edu and the IODP Expedition 342 Scientists

\section{Photo Credits}

Fig. 2a-c: Peter Flemings, The Unicersity of Texas at Austin Fig. 2d: William Crawford, IODP-TAMU

\section{Related Web Links}

http://www.iodp.org/Science-Plan-for-2013-2023/ http://www.ig.utexas.edu/research/facilities/downhole/ mdhds.htm 